\title{
ГАЛИЦЬКЕ КНЯЗІВСТВО І ПОВСТАННЯ БОЛГАР У СЕРЕДИНІ 80-Х РОКІВ ХІІ СТ.
}

\author{
О. Б. Козачок
}

Козачок О. Б. Галицьке князівство і повстання болгар у середині 80-х років ХII ст. Переглянуто роль руського населення Нижнього Подунав'я в антивізантійському повстанні болгар з середини 80-х років XII ст. 3'ясовано, що думка про допомогу Галицького князівства Болгарії під час повстання грунтується на таких аргументах: географічна близькість, ймовірне перебування у Галичі на початку XIII ст. спадкоємця болгарського престолу Івана Асеня II та результати співставлення відомостей візантійських хронік зі свідченнями «Слова о полку Ігоревім». Зроблено висновок, що восени 1186 р. військову підтримку болгарам надали бродники.

Ключові слова: Візантія; Галицьке князівство; Друге Болгарське Царство; бродники; повстання болгар; Нижнє Подунав'я.

Козачок О. Б. Галицкое княжество и восстание болгар в середине 80-х годов ХІІ в. Пересмотрена роль русского населения Нижнего Подунавья в антивизантийском восстании болгар с середины 80-х годов XII в. Установлено, что мысль о помощи Галицкого княжества Болгарии во время восстания основывается на таких аргументах: географическая близость, вероятное пребывания в Галиче в начале XIII в. наследника болгарского престола Ивана Асеня II и результаты сопоставления сведений византийских хроник со свидетельствами «Слова о полку Игореве». Сделан вывод, что осенью 1186 г. военную поддержку болгарам предоставили бродники.

Ключевые слова: Византия; Галицкое княжество; Второе Болгарское Царство; бродники; восстание болгар; Нижнее Подунавье.

Kozachok O. B. The Galician Principality and the Bulgarian uprising in the mid 80s of the 12th century. Role of the Rus population of the Lower Danube in the Bulgarian anti-Byzantine uprising from the mid 80 s of the 12 th century is reconsidered in the paper. It was found out that the idea of aid of the Galician Principality to the Bulgarians during the uprising is based on the following arguments: geographical proximity, probable stay in Galicia in the early 13th century the heir to the Bulgarian throne Ivan Asen II and the results of comparison of data of the Byzantine chronicles with data of "The Lay of Igor's Campaign". It is concluded that in autumn of 1186 Brodnics provided Bulgarians with military aid.

Keywords: Byzantium; the Galician Principality; the Second Bulgarian Tsardom; the Brodnics; the Bulgarian Uprising; the Lower Danube Region.

Микита Хоніат у похвальній промові Ісааку II Ангелу, яку датують 1190 p. ${ }^{1}$, описував останні звитяги імператора. Розповідаючи про поразку, завдану болгарам 1186 р., він відзначив, що на боці повстанців були «скіфи» (половці) та «ті з Вордони, які зневажають смерть, гілка тавроскіфів, народ, що також поклоняється Арею, допомагали варварам на Гемі, схилились разом з ними, переможеними, і разом загинули» [переклад за Геннадієм

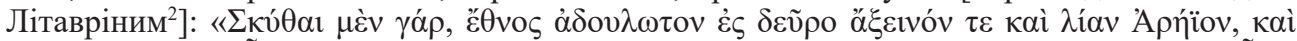

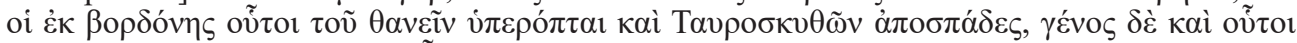

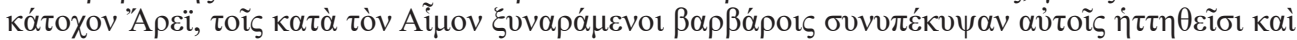
$\sigma v v \alpha \pi \omega ́ \lambda о v \tau о »{ }^{3}$. Цей фрагмент промови спричинив дискусію щодо причетності русько-

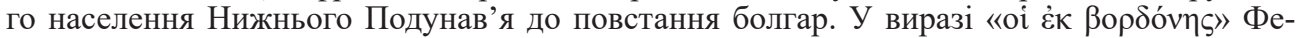
дір Успенський розпізнав спотворену назву «бродників», а під «тавроскіфами» звично мали проглядатися руси. Тому, переважно, у союзниках болгар вбачають бродників ${ }^{4}$.

Зіставляючи свідчення «Слова о полку Ігоревім» 3 даними візантійських джерел про перебіг болгарського повстання, спершу Михайло Тихомиров, потім Леонтій Войтович схилялися до визнання певного стосунку галицького володаря Ярослава Володимировича до подій середини 80 -х років, адже територія бродників перебувала у межах впливу Галицького князівства. Крім того, через підконтрольні Галичу Нижнє Подунав'я і Подністров'я на допомогу болгарам проходили половецькі війська ${ }^{5}$. На думку Л. Войтовича, «відроджена Болгарська держава не могла в короткий час організувати власне ли- 
царське військо, тому на перших етапах Асені спиралися на галицьку допомогу (тих, що походять з Вордони), половців та волохів» 6 .

Погоджуючись 3 тезою про підтримку русами болгар, дослідники не вдаються до глибшого аналізу ситуації. Відсутність зацікавлення - наслідок малочисельності джерел. Промови та листи Микити Хоніата впроваджено до наукового вжитку значно пізніше, ніж його «Історія», понад століття тому. У літературі, звично використовуючи хроніку, згадану промову часто оминають увагою. Інші джерела цього епізоду не фіксують, тому «руське питання» у загальному контексті досліджень повстання фігурує рідко. Якщо ж вказаний уривок аналізується, то повідомлення про тавроскіфів-бродників часто відносять до куманів, вбачаючи в них головних союзників болгар ${ }^{7}$

Потребу заново розглянути роль руського населення Нижнього Подунав'я у повстанні болгар зумовила поява нових досліджень щодо бродників та суперечок навколо їх участі, сприйняття якої коливається від епізодичної появи на сторінках болгарської історії до внеску у відновлення Болгарської держави. 3'ясування причетності до подій Галицького князівства дасть змогу краще зрозуміти характер його відносин з Візантією наприкінці XII ст.

У 80-х роках Візантійська імперія переживала кризу через внутрішні та зовнішні виклики: нависла небезпека з боку Іконійського султанату, Венеції, Угорщини, ймовірність нового виступу сербів за угорської підтримки й утворення болгарсько-половецької коаліції. Поглинуті внутрішніми негараздами, Константинополь і Галич не контактували. Зважаючи на амбіції Візантії у церковній сфері, істотного значення для імперії в цей час набули відносини з Київським князівством ${ }^{8}$. Лише під 1185 р. Михаїл Хоніат повідомив про прибуття до Константинополя посольства «скіфа», під яким розуміють галицького князя9. Про результати візиту нічого не відомо. Проте, саме цей час вважають переломним у галицько-візантійських відносинах. Вбивство двоюрідного брата князя Ярослава - Андроніка (вересень 1185 р.) ${ }^{10}$ та відсутність підтвердження союзу під час посольства спровокувало розірвання відносин i, як вважають, це вилилося у рішення галицького князя підтримати болгарських повстанців ${ }^{11}$.

3 переходом Болгарії під владу Візантійської імперії й активним рухом кочовиків через Нижнє Подунав'я, русько-болгарські зв'язки ослабли, оскільки Русь і Болгарію відділяли печеніги, потім половці ${ }^{12}$. За все XII ст. у джерелах немає звісток про русько-болгарські чи, конкретно, болгарсько-галицькі відносини. Але В. Татіщев під 1152 р. залишив повідомлення про намір київського князя Ізяслава Мстиславовича помститися Володимиркові Володаревичу, для чого, однак не мав достатніх військових сил. Натомість «Володимирко, значну допомогу від болгар отримуючи, сильний був ${ }^{13} \ldots$ дізнавшись, що угорський король, увійшовши в згоду з Ізяславом великим князем, на нього хочуть йти, велів негайно всім своїм військам від Дунаю і цього боку Дністра до Галича збиратися, а також найняв болгар і сербів 30 000, які, прийшовши за гроші, стали на Дністрі поблизу Галича. I було його війська більше $70000 »^{14}$. У продовженні розповіді про київсько-угорську кампанію проти галицького князя, вказано: «Зійшлися на тому, щоб рано-вранці йти всім до ріки Сан, де Володимирко зі своїми полками і найманими болгарами, з немалим військом, укріпившись, стояв» ${ }^{15}$. Цієї інформації не підтверджують літописні дані, тому говорити про галицько-болгарську військову взаємодію не випадає. Відомо лише про підтримку торгівельних, культурних і релігійних зв'язків між Тирново та Галичем.

Четверта (за ХІІ ст.) візантійсько-угорська війна завершилася мирним договором 1185 p. й союзом на противагу німецько-норманському об'єднанню. Політичний союз закріпив шлюб Ісаака II Ангела 3 донькою угорського короля Бели III - Маргаритою ${ }^{16}$. Підвищення податків для покриття витрат на весілля стало однією з причин повстання ${ }^{17}$. Дослідники приділяють цьому фактору чи не найбільше уваги ${ }^{18}$. Як писав Георгій Акрополіт, з болгар тоді взято більше, ніж з інших провінцій ${ }^{19}$. Інший чинник - відмова імператора зарахувати Петра і Асеня до військового прошарку ${ }^{20}$. На думку Ф. Успенського, обурення новим податком та відмова братам у військовому званні не могли бути безпосередніми причинами повстання. Візантія одразу не сприйняла серйозно процесів, які відбувалися у Болгарії ${ }^{21}$.

Зважаючи на відсутність прямих вказівок щодо участі русів у подіях середини 80-х років та порушене датування в «Історії» Микити Хоніата, складно зрозуміти, коли «тавроскіфи з Вордони» разом з болгарами вступили до боротьби. За Хоніатом послідовність подій така: 1) підвищення податків і реквізиція худоби для організації весілля Iсаака II, що 
викликає гнів «варварів Гемської гори»; 2) брати Асені прибувають до імператора, натякаючи на дії проти ромеїв; 3) шлюб Ісаака II Ангела; 4) початок конфронтації з болгарами та зміна керівництва візантійської армії. Спочатку Ісаак II призначив свого дядька севастократора Іоана, якого згодом запідозрив у намірах посісти царство ${ }^{22}$. Потім командування військом покладено на зятя імператора - Іоана Кантакузина ${ }^{23}$, проте він невдало вів війну проти повстанців. Його заступив полководець Алексій Врана, який розпочав бунт і проголосив себе імператором в Адріанополі. Така ситуація сприяла активності повстанців у фракійській низовині. Більшість дослідників погоджуються з таким датуванням: листопад 1185 р. - Асені з'являються на аудієнції у візантійського імператора; листопад-грудень укладення візантійсько-угорського миру та підвищення податків; кінець 1185 чи початок 1186 р. - шлюб ${ }^{24}$; весна 1186 - початок повстання ${ }^{25}$.

Організований збройний виступ болгар почався влітку 1186 р. 3 території північносхідних Балкан, де влада ромеїв була значно слабшою, ніж у рівнинних областях ${ }^{26}$. Тоді Ісаак II здійснив першу кампанію проти повсталих ${ }^{27}$. Як наслідок, Асені були змушені шукати підмоги за Дунаєм. Микита Хоніат тричі писав про переправу болгар через Дунай за підкріпленням. Перші два випадки стосувалися цього походу, третій - пізнішого. Отже,

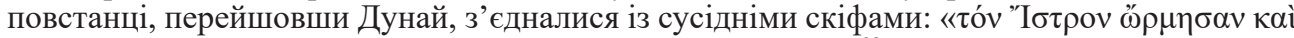

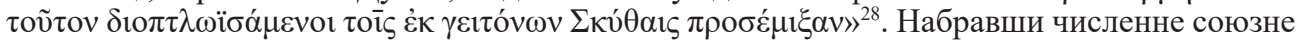

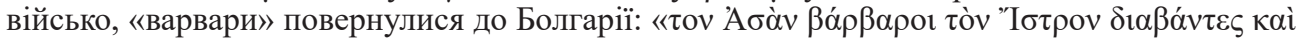

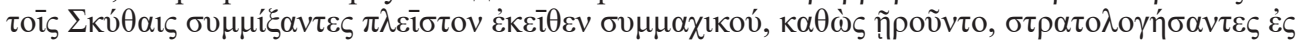

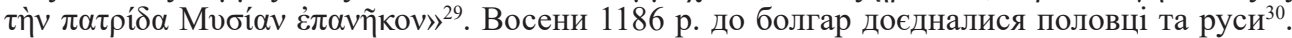
Половцям в обмін на військову допомогу Асені обіцяли свободу дій на ромейських землях - грабунки ${ }^{31}$. На думку В. Пашуто, союзниками болгар стали якраз згадані в літописі «подунайці» чи «поістрійські скіфи» візантійських джерел ${ }^{32}$.

Повернімося до тексту цитованої промови Микити Хоніата й спробуємо ідентифікува-

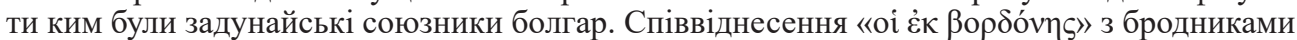

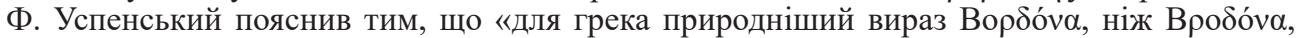
тобто бродня ${ }^{33}$, і навів приклади спотворень назви «землі бродників» у латиномовних джерелах першої половини XIII ст. В угорських документах королі, розпоряджаючись трансільванськими землями, позначали територію на схід від Угорщини: «terram que vadit usque ad terminus Prodnicorum» (1222 p. $)^{34}$, «terre Borotnik» (1223 p. $)^{35}$. Папа Григорій IX у своїх дорученнях 1227, 1231 рр. писав про ведення місіонерської діяльності «іn Cumania et Brodinia terra», «in Cumanorum et Brodnicorum provinciis» ${ }^{36}$. Востаннє бродники («Brodniсi») фігурують у листі Бели IV до папи Інокентія IV 1254 p. ${ }^{37}$.

Федон Малінгудіс, прийнявши деякі висновки Федора Успенського, твердив, нібито від спотвореного Вордона складно утворити етнікон «бродники», тому йшлося про по-

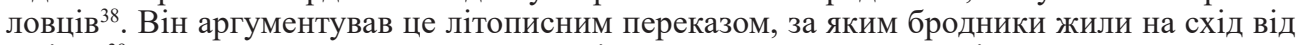
Дніпра ${ }^{39}$. Це твердження виникло внаслідок упущення з уваги свідчень згаданих угорських грамот. Як зауважив Олександр Головко, «автори візантійських, угорських та римських пам'яток мали уявлення лише про найближче до кордонів їх держав населення, тим більше, що ці відомості пов'язані з конкретними політичними діями» ${ }^{40}$, тому використання лише одного пласту джерел дає викривлений погляд на ситуацію. До того ж, значення «бродити» Ф. Малінгудіс виводив від «блукати», а не «переходити брід», що, на його думку, є підтвердженням вказівки на половців ${ }^{41}$. Додатковим аргументом слугувало виявлене на лівобережжі Дунаю поселення «Куманський брід», відтак бродники - теж кумани ${ }^{42}$. Відкликаючись до повідомлення літопису про похід придніпровських половців до Дунаю 1187 р., Ф. Малінгудіс протрактував його прикладом допомоги болгарам ${ }^{43}$. Однак досить складно пов'язати похід 1187 р. 3 перебігом повстання, адже половці стали його учасниками попереднього року. Крім того, якщо опиратися на Хоніата, територія болгарських союзників починається за Дунаєм. Г. Літаврін, не відкидаючи ідеї співучасті придніпровських половців, вказав на логічність пошуку союзників поблизу театру подій ${ }^{44}$, адже повстанці одразу поверталися до «Мізії», й, очевидно, не могли розраховувати на швидку допомогу здалеку.

Причину наполегливого ототожнення бродників з куманами можна зрозуміти. Про їхню військову допомогу болгарам відомо на усіх етапах повстання. У промовах ефеського митрополита Георгія Торніка, посланнях до Iсаака II Ангела візантійських риторів XII ст. 
Сергія Коліви та Іоана Сіропулоса союзниками болгар виступали кумани ${ }^{45}$. Як засвідчують західноєвропейські хроніки, надалі половці брали участь у походах болгарського царя Калояна (1197-1207) ${ }^{46}$. Факти спільних дій бродників і кочовиків на боці болгар та в битві на р. Калці для деяких дослідників слугують підтвердженням того, що їх основу становили тюрки ${ }^{47}$. О. Головко, проаналізувавши свідчення Суздальського та Галицько-Волинського літописів, дійшов висновку: «Під час подій 1223 р. різні частини слов'янського населення півдня опинилися в різних таборах воюючих. Бродники, про яких є згадки в Суздальському літописі, мешкали в регіоні від Дону до Дніпра. Їм першим загрожували монголо-татарські війська, особливо після розгрому східного об'єднання половців на чолі з Юрієм Кончаковичем. Саме така ситуація змусила їх перейти на бік ворогів. Населення ж Подністров'я та низин Дунаю - «выгонцы Галичькыя» - підтримало коаліцію південноруських князів ${ }^{48}$.

Все ж, більшість дослідників наполягають на переважанні слов'янського елементу серед бродників ${ }^{49}$. Підтвердження цьому знаходять у літописі під $1223 \mathrm{p}^{50}$ - розповіді про те, як воєвода бродників Плоскиня цілував хрест київському князеві Мстиславу ${ }^{51}$, та угорських джерелах, де під 1247 р. волоського воєводу названо слов'янським іменем Всеслав чи Станіслав ${ }^{52}$. Пламен Павлов вважав природним союз болгар з бродниками, адже ті, як слов'яни, православні, маючи схожу мову, могли легше домовитися, а те, що вони охороняли броди, були «людьми меча» $\mathrm{i}$, як писав дослідник, «перебували в тісному контакті 3 куманами», пояснює їх залучення до повстання ${ }^{53}$.

Г. Літаврін звернув увагу, що Микита Хоніат писав не про «скіфів з Вордони», як твердив Ф. Малінгудіс ${ }^{54}$, а «тавроскіфів» і це переводить дискусію в інше русло. Тому Г. Літаврін запропонував розглянути проблему участі русів у повстанні окремо від з'ясування походження бродників ${ }^{55}$. Плутанину вносять самі дослідники, безпідставно ототожнюючи «тавроскіфів» Хоніата 3 куманами ${ }^{56}$ або стверджуючи, що коли хроністи вживають «Рос», йдеться про Київське князівство, а Галицьке позначається локальною назвою «Галіца» ${ }^{57}$. У зв'язку із цим, ставимо перед собою завдання систематизувати розрізнені свідчення, щоб показати цілісніший погляд на «тавроскіфів» у праці візантійського хроніста. Можемо виокремити ототожнення «тавроскіфів» і руських. Зокрема, Хоніат писав про чвари між тавроскіфами - київським князем Рюриком і галицьким правителем Романом ${ }^{58}$, що «тавроскіфи» та інші народи перейняли від ромеїв «звичай» братовбивства ${ }^{59}$. В усіх інших згадках «тавроскіфи» мали безпосередній стосунок до Галицького князівства, коли йшлося про першу втечу Андроніка ${ }^{60}$, його рішення вдруге тікати до Галича ${ }^{61}$, де він перейняв жорстокі звичаі ${ }^{62}$ та наказ Андроніка зробити фрески в храмі Сорока мучеників із зображенням сцен полювання і зубра, який водиться переважно у «тавроскіфів» ${ }^{63}$. Описуючи приготування Мануїла Комніна до війни з угорцями, Хоніат писав, що угорський король тоді воював із сусідніми росами ${ }^{64}$. Тут $є$ чітка вказівка на Галицьке князівство. Крім того, коли йдеться про

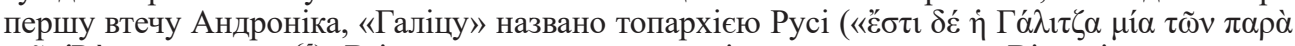

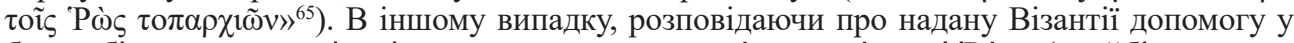

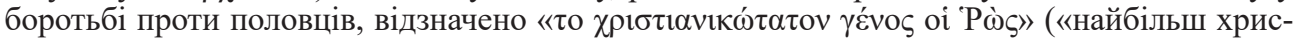
тиянський народ руський» $\left.{ }^{66}\right)$, князі якого виявили готовність допомогти ромеям, серед них і Роман Мстиславович, за візантійськими джерелами «галицький гегемон».

Отже, Микита Хоніат добре розрізняв «скіфів» і «тавроскіфів» й коли розповідав про останніх, не виникає сумнівів, що йдеться про русів. Крім того, нелогічною видається подвійна вказівка в одному реченні на участь половців на боці болгар. Ф. Успенський, аналізуючи «Історію», вказав на події, спосіб викладу яких свідчить про особисту присутність у них Хоніата, зокрема похід Ісаака II проти болгар 1188 р. i 1189 р. та згадка про довірене Хоніату управління філіппопольською фемою ${ }^{67}$. Микита, як учасник боротьби Ісаака проти болгар до 1195 р., описує стан справ 3 власних спостережень ${ }^{68}$. Тож, будучи свідком і учасником подій, він навряд чи міг істотно наплутати. Інший сучасник - Іоан Кіннам 11 разів писав про «тавроскіфів» та 1 раз - «притаврських скіфів», ототожнюючи ïx $з$ русами, з них 8 згадок стосуються Галицького князівства ${ }^{69}$.

Те, що візантійські хроністи під «тавроскіфами» здебільшого мали на увазі «галичан» підштовхує до думки про можливу участь галицького князя у повстанні. Л. Войтович, переймаючи інтерпретацію «Слова о полку Ігоревім» М. Тихомирова, який пов’язує панегірик Ярославові Осмомислу з подіями в Болгарії 1186-1187 рр., вбачав у цьому підтвер- 
дження такої ідеї. Вчені відштовхувалися від припущення про обізнаність автора «Слова» 3 болгарською ситуацією і негативною реакцією на неї угорського короля ${ }^{70}$. Зокрема, у фразі «підпер гори угорські своїми залізними полками, заступив королеві путь» ${ }^{71}$ вбачали блокування Залізних воріт, звідки могли виступити угорці72. У цих словах М. Тихомиров дошукувався, з одного боку, відсутність загрози від сусідньої Угорщини, з іншого - напруженість галицько-угорських відносин ${ }^{73}$. Вираз «меча бремени чрез облаки» інтерпретують як опис переправи військових знарядь, стінобитних машин, а фраза «рища тропу Траяню чрез поля на горы» повинна стосуватися «гірського шляху в Балканах, відомого під назвою Троянової дороги» ${ }^{74}$.

На перше припущення можна навести контраргумент, інші складно підтвердити чи заперечити. Угорський правитель, справді, зайняв ворожу позицію щодо болгар. Проте практично її реалізовано значно пізніше. Лише після того, як візантійські війська зазнали серйозної поразки від болгар при Аркадіополі 1194 р., Ісаак II Ангел звернувся до Бели III 3 проханням про військову допомогу і той погодився ії надати ${ }^{75}$. Щодо двох інших виразів існує значна кількість тлумачень. Якщо дослідники «Слова», здебільшого, погоджуються 3 тим, що під «меча бремени чрез облаки» малася на увазі військова потуга Ярослава Володимировича ${ }^{76}$, то вираз про «загадкового» Траяна, тричі згаданого у тексті, спровокував появу кількох течій з відмінними трактуваннями, хоч деякі представники історичного напряму в «тропі Траяна» вбачають шлях від Дунаю до Карпатських гір через Валахію 77. Л. Войтович звернув увагу на рядки про Траяна у зв'язку з тим, що «Карпатська лінія оборони була неприступною і тому походи угорського війська на Галич відбувалися в іiї обхід через Сянок і Перемишль» ${ }^{78}$. В історіографії вже здійснено деякі дослідження середньовічних шляхів через Карпати, але локалізувати їх дуже складно ${ }^{79}$. Все ж, згадка про Траяна у «Слові» з'являється не у контексті розповіді про Ярослава Осмомисла, а далі в тексті, тому прив'язування цього виразу до загального тлумачення викликає сумніви.

Підтвердженням стосунку галицького князя до подій 1186 р. вважають «повторне» звернення болгар до Галича на початку ХІІІ ст. Зі смертю болгарського царя Калояна у 1207 p. із синами Івана I Асеня - Іваном II Асенем та Александром почав конкурувати за престол племінник Калояна Борил. Вони мали досить слабкі позиції через малий вік (Іванові Асеню було близько 16-17 р., Александр - на 2-3 роки молодший), відсутність авторитету в середовищі армії, боярства і суспільства ${ }^{80}$. За хронікою Георгія Акрополіта, Іоан втік до країни русів, де після тривалого перебування зібрав руські дружини для повернення на батьківщину. У результаті, він переміг Борила і заволодів великою країною (1218р.):

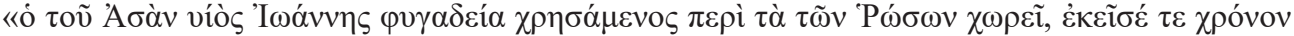

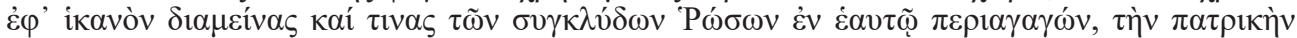

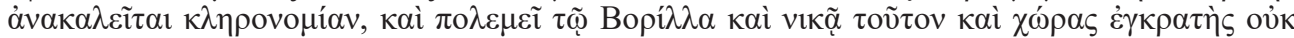

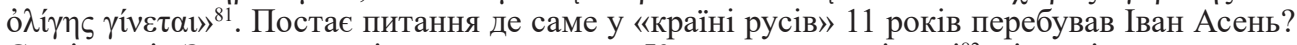
$€$ дві версії. За першою, він переховувався у Київському князівстві ${ }^{82}$, відповідно, на думку Володимира Пашуто, руська допомога надійшла 3 причорноморського Пониззяя ${ }^{83}$, за другою - знайшов притулок у Галицькому князівстві ${ }^{84}$. Часто це питання просто опускають, не вдаючись до конкретизації і з'ясування можливості русько-болгарських контактів ${ }^{85}$. На думку Л. Войтовича, лише Галицьке князівство могло бути зацікавлене у наданні такої допомоги й припустив, що Ігоревичі мали обіцяти іiї Іванові II, але, зважаючи на внутрішні галицькі колізії, піддав сумніву можливість реалізації цієї допомоги ${ }^{86}$. Половці були союзниками Борила, тому в них він затримуватися не міг, а «Київ був надто далеко і тамтешні правителі вже давно не виявляли інтересу до Нижнього Подунав'я» ${ }^{87}$. У версії про Галич дивує те, що незадовго до того Роман Мстиславович здійснив кілька походів проти болгарсько-половецьких сил. Чи не головним аргументом проти цієї версії є внутрішня політична криза та угорський тиск, який посилився на початку XIII ст. 3 одного боку, галицько-угорські колізії робили неможливим надання допомоги болгарам, 3 другого саме протистояння з Угорщиною виступало пунктом перетину інтересів Галича і Тирново. В. Пашуто писав: «Союз з Болгарією був природним для Русі, що остерігалася втручання Угорщини і папства у справи Галичини. Конфлікти з Угорщиною 1201-1202, 1210, 1230 рр., у свою чергу, зближували Болгарію з Галичиною» ${ }^{88}$.

Єронім Граля назвав побутування в історіографії тези про наявність відносин між Галицьким князівством і Болгарією наприкінці XII - на початку XIII ст. та надання остан- 
ній допомоги прикладом поганої праці з джерелами й зауважив на потребі звернутися до оригіналу хроніки Георгія Акрополіта, а не перекладу 150 -літньої давнини ${ }^{89}$. Зважаючи на тогочасну політичну ситуацію, дослідник відкинув можливість участі галицьких полків на боці Асенів. Проте використання автентичного тексту, його порівняння 3 російським перекладом, іншими виданнями суттєво ситуації не змінює, лише дає змогу внести деякі корективи. Зокрема, в історіографії (від В. Пашуто) блукає думка про участь «галицьких вигінців» у боротьбі Івана Асеня II за болгарський престол ${ }^{90}$. Тут, очевидно, допущено помилку в перекладі хроніки Георгія Акрополіта. Візантійський автор вживає слово

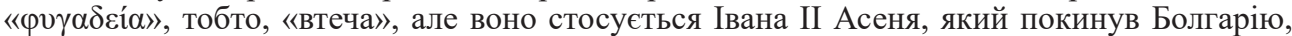
а не русів, котрі прийшли йому на допомогу. Втім, коли під «вигінцями» мати на увазі «тих, що жили на вигоні», тоді це набуває сенсу. Дослідники погоджуються, що Іванові II Асеню надали допомогу жителі Нижнього Подунав'я, «слов'яни-подунайці» ${ }^{11}$. П. Павлов - прихильник першої версії - свою позицію аргументував повідомленням Акрополіта про перебування царевича в «країні руській», тобто Київському князівстві, а військо Івана

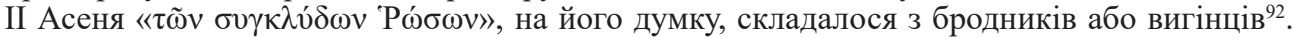
Відгомін тих подій знаходимо у «Похвальному слові на чудеса Святого Димитрія Солунського» Іоана Ставракія. Серед союзників Іоана II Асеня тут названо «всякого роду росів,

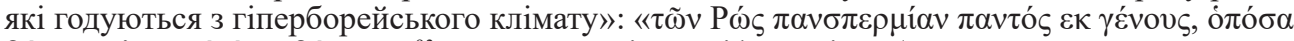

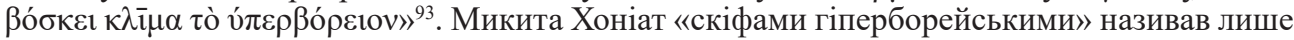
жителів Галицького князівства ${ }^{94}$, а пізніший автор Никифор Григора писав про велику і густонаселену Русь, розташовану частково «на гіперборейських (північних) землях», або «поміж гіперборейськими горами» ${ }^{95}$.

С міркування, що деякі болгарські міста в усті Дністра та на Дунаї у Воскресенському літописі були зараховані до руських через пам’ять про їхню участь в болгарських справах у XIII-XIV ст., хоч цьому складно знайти пояснення. Вперше таку думку висловив російський вчений XIX ст. Філіп Брун ${ }^{96}$. П. Павлов, не виключаючи можливості інших подій, пов'язаних з участю русів, за період XII-XIV ст. відзначив, головно, взаємний культурний вплив ${ }^{97}$.

Михайло Бібіков, розглядаючи повідомлення Миколая Месарита - очевидця бунту Іоана Комніна Товстого 1201 р., учасники якого «вимагали, щоб ромеїв не перемагали ні «скіф», ні «болгарин», ні «тавроскіф», ні інші «варвари»" вині XII - на межі XIII ст. могли відбуватися русько-візантійські зіткнення ${ }^{99}$. Справді, ця згадка, окрім епізоду участі «тавроскіфів» у боротьбі на боці болгар, жодних інших асоціацій не викликає. За періоду правління Мануїла I та Алексія II Комнінів джерела не дають натяку на можливі візантійсько-галицькі конфлікти. Коли ж до влади в Галичі прийшов Роман Мстиславович, він став союзником імперії проти болгарсько-половецьких військ.

Утворення Другого Болгарського царства та зосередження на Нижньому Дунаї значної кількості половців призвело до заворушень на Балканах. Те, що болгари зуміли організувати повстання, заручитися підтримкою кочовиків і здійснити кілька походів, загрожуючи навіть Константинополю, послабило вплив Візантії на цих теренах, а згодом призвело до втрати іiі контролю над Нижнім Подунав'ям. Але не можна цілком погодитися iз тим, що нібито в першій половині XIII ст. «Нижнє Подунав'я трансформувалося 3 контактної візантійсько-галицької на контактну болгаро-галицьку зону» ${ }^{100}$. Надання болгарам допомоги мало укріпити русько-болгарські відносини ${ }^{101}$. Окрім половецької присутності, підтримувати владу над Подунав'ям на межі XII-XIII ст. Галицькому князівству заважала політика Угорщини, спрямована на заволодіння Східним Прикарпаттям. Візантійсько-галицькі відносини після Романа Мстиславовича не мали розвитку. Зважаючи на розпачливе становище після 1204 р., імперія намагалися утримати зв'язок із Київською митрополією як, мабуть, останнім важелем впливу на той час.

Отже, бродники восени 1186 р. в ході повстання, та, як засвідчують джерела, ще кілька разів упродовж першої третини ХІІІ ст. надавали військову підтримку болгарам. Хоча, вони - «тавроскіфи» нижньодунайських земель - перебували під впливом Галицького князівства, неможливо довести, що їх участь була ініціативою галицького князя. За хронологією Ярослав Володимирович, справді, міг надати допомогу повстанцям і мав мотив (реакція на вбивство Андроніка Комніна), однак можливість виступу проти імперії видається сумнівною. Адже сам князь у походах участі не брав, лише споряджав війська, 
до того ж уникав конфліктів імперії з іншими державами. Вираз «Слова», радше, означав закріплення Подунав'я за Галицьким князівством і те, що угорському королю шлях туди обмежено. Тому Ярославові Володимировичу, який у той час був більше зайнятий протистоянням із боярською опозицією, відводиться пасивна роль - безперешкодний пропуск військ через Нижній Дунай на допомогу болгарам. Для бродників, як і половців, військові дії були способом збагатитися, але, не применшуючи значення їх допомоги на першому етапі боротьби, на противагу куманам, їхня роль у повстанні епізодична.

${ }^{1}$ Бибиков M. B. Byzantinorossica: Свод византийских свидетельств о Руси. Нарративные памятники. М., 2004. Т. 1. С. 373.

2 Литаврин Г. Г. Два етюда о восстании Петра и Асеня // Византия и славяне. М., 1999. С. 354.

${ }^{3}$ Nicetae Choniatae Orationes et epistulae // Corpus fontium historiae Byzantinae. Berolini, 1972. P. 93.18-22.

${ }^{4}$ Котляр М. Давньоруські корені козацтва // Українське козацтво: витоки, еволюція, спадщина. Матеріали міжнародної наукової конференції, присвяченої 500-річчю українського козацтва (КиївДніпропетровськ, 13-17 травня 1991 р.). К., 1993. Вип. 1. С. 36; Литаврин Г. Г. Два етюда... С. 354; Успенский Ф. И. Участіе Русскихъ въ борьбъ за независимость // Успенский Ф. И. Образованіе Втораго Болгарскаго царства. Одесса, 1879. С. 35-36; Князький И. О. Русь и Степь. М., 1996. С. 61; Пашуто В. Т. Внешняя политика Древней Руси. М., 1968. С. 200; Цанкова-Петкова Г. България при Асеневци. София, 1978. С. 27.

${ }^{5}$ Тихомиров М. Н. Древняя Русь. М., 1975. С. 33; Войтович Л. В. Перша галицька династія // Генеалогічні записки. Львів, 2009. Вип. 7. С. 15.

${ }^{6}$ Войтович Л. В. Галицько-болгарські відносини у першій третині XIII століття // Княжа доба: Історія і культура. Львів, 2010. Вип. 3. С. 202, 205; Войтович Л. В. Границы Галицко-Волынского государства // Русин. Международный исторический журнал. Кишенев, 2011. № 3 (25). С. 21.

7 Андреев Й. История на Второто българско царство. Тырново, 1996. С. 32; Божилов И. Фамилията на Асеневци (1186-1460). Генеалогия и просопография. София, 1994. С. 29; Божилов И., Гюзелев В. История на средновековна България VII-XIV век / История на България в три тома. София, 1999. Т. 1. С. 430; Дуйчев И. Проучвания вьрху бьлгарското средневековие. София, 1945. С. 55; Иречекъ К. І. Исторія болгаръ / Пер. с чешского Ф. К. Бруна, В. Н. Палаузова. Одесса, 1878. C. 301-304; Ritter M. Die vlacho-bulgarische Rebellion und die Versuche ihrer Niederschlagung durch Kaiser Isaakios II. (1185-1195) // Byzantinoslavica. Revue internationale des Etudes Byzantines. Prague, 2013. № 1-2. S. 183.

8 Литаврин Г. Г. Русско-византийские отношения в XI-XII вв. / История Византии: В 3 т. М., 1967. T. 2. C. 351.

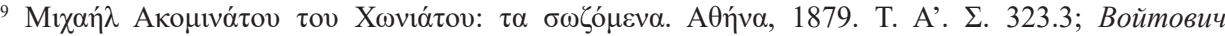
Л. В. Перша галицька династія. С. 14; Бибиков М. В. Древняя Русь и Византия в свете новых и малоизвестных византийских источников // Восточная Европа в древности и средневековье. Чтения памяти члена-корреспондента АН СССР Владимира Терентьевича Пашуто. М., 1978. С. 299-300.

${ }^{10}$ Юревич О. Андроник I Комнин / Пер. с англ. К. Л. Дробинской. СПб., 2004. С. 242.

${ }^{11}$ Войтович Л. В. Союз Візантії та Галицько-Волинської держави за династії Ангелів // Княжа доба: історія і культура. Львів, 2008. Вип. 2. С. 36; Литаврин Г. Г. Становление Второго Болгарского царства и его международное значение в XIII столетии // Византия и славяне. М., 1999. С. 372; Тихомиров М. Н. Древняя Русь. С. 32; Maiorov A. The Alliance between Byzantium and Rus' Before the Conquest of Constantinople by the Crusaders in 1204 // Russian History. Brill, 2015. Vol. 42. Issue 3. P. 301.

${ }_{12}$ Пашуто В. Т. Внешняя политика... С. 202.

${ }^{13}$ Татищев В. История Российская. В 3 т. М., 2003. Т. 2. С. 272.

${ }^{14}$ Там же. С. 274.

${ }^{15}$ Там же.

${ }^{16}$ Nicetae Choniatae Historia // Corpus fontium historiae Byzantinae. Berolini, 1975. P. 1: Praefationem et textum continens. Vol. XI, 1: Series Berolinensis. P. 368.

${ }^{17}$ Ibidem. P. 368.44-52.

${ }^{18}$ Ангелов Д. С. Восстание Асеней и восстановление средневекового Болгарского государства // Византийский временник. М., 1986. Т. 47 (72). С. 57; Каждан А. П., Литаврин Г. Г. Южнословянские народы под властью Византии // Очерки истории Византии и южных славян. СПб, 1998. С. 191; Литаврин Г. Г. Новое исследование о восстании в Паристрионе и образовании Второго Болгарского царства // Византийский Временник. М., 1980. Т. 41 (66). С. 94; Madgearu A. Frontiera dunăreană a Imperiului Bizantin în secolul al XII-lea // History \& Politics. Chişinău, 2008. № 1-2. P. 124.

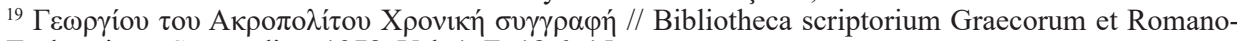
rum Teubneriana. Stutgardiae, 1978. Vol. 1. $\Sigma$. 18.6-15.

${ }^{20}$ Nicetae Choniatae Historia. P. 368. 58-69. 
${ }^{21}$ Успенский Ф. И. Образованіе... С. 109.

${ }^{22}$ Nicetae Choniatae Historia. P. 374.88-95.

${ }^{23}$ Ibid. P. 374.96-97.

${ }^{24}$ Успенский Ф. И. Образованіе... С. 117; Madgearu A. Confrontations between Hungary, the Byzantine Empire and Bulgaria for the Belgrade-Vidin Border Region // Transylvanian Review. 2013. Vol. 22. P. 128.

${ }^{25}$ Литаврин Г. Г. Новое исследование... С. 101.

${ }^{26}$ Каждан А. П., Литаврин Г. Г. Южнословянские народы... С. 197; Ангелов Д. С. Восстание Асеней... С. 55.

${ }^{27}$ Литаврин Г. Г. Два етюда... С. 354; Ангелов Д. С. Восстание Асеней... С. 60.

${ }^{28}$ Nicetae Choniatae Historia. P. 373.58-59.

${ }^{29}$ Ibid. P. 374.79-81.

${ }^{30}$ Ангелов Д. С. Восстание Асеней... С. 61; Литаврин Г. Г. Два етюда... С. 362.

${ }^{31}$ Ritter M. Die vlacho-bulgarische Rebellion... S. 183.

32 Паиуто В. Т. Внешняя политика... С. 202-203.

${ }^{33}$ Успенский Ф. И. Участіе Русскихъ... С. 35-36.

${ }^{34}$ Fontes rerum Austriacarum: Abt. 2. Diplomataria et acta. Wien, 1857. Vol. 15. P. 18.

${ }^{35}$ Ibid. P. 23.

${ }^{36}$ Котляр М. Ф. Русь на Дунаї // Український історичний журнал. К., 1966. № 9. С. 19.

${ }^{37}$ Котляр М. Давньоруські корені козацтва. С. 38.

${ }^{38}$ Malingoudis Ph. Die Nachrichten des Nicetas Choniates über die Entstehung des Zweiten Bulgarischen Staates // Byzantina. Thessaloniki, 1978. Vol. 10. P. 136.

${ }^{39}$ Ипатьевская летопись // Полное собрание русских летописей. М., 1962. Т. 2. С. 342.

40 Головко О. Б. Слов'яни Північного Причорномор'я доби Київської Русі та проблема витоків українського козацтва // Український історичний журнал. К., 1991. № 11. С. 32. О. Головко висновує, що «бродники у широкому розумінні цього слова - східнослов'янське населення, котре мешкало в Південно-Східній Свропі і не підкорялося або майже не підкорялося князівській адміністрації» (Головко О. Б. Слов'яни Північного Причорномор'я... С. 33).

41 Литаврин Г. Г. Два етюда... С. 355-356.

${ }^{42}$ Malingoudis Ph. Die Nachrichten des Nicetas Choniates... P. 137.

${ }^{43}$ Ibid.

44 Литаврин Г. Г. Два етюда... С. 357.

45 Дуйчев И. Проучвания вьрху бьлгарското средневековие. С. 55-57, 80.

${ }^{46}$ Виллардуэн Жоффруа де. Взятие Константинополя. Песни труверов / Пер. со старофранц. О. Смолицкой и А. Парина. М., 1984. С. 150-152

${ }^{47}$ Spinei $V$. The Romanians and the Turkic Nomads North of the Danube Delta from the Tenth to the Mid-Thirteenth Century / East Central and Eastern Europe in the Middle Ages, 450-1450. Leiden-Boston, 2009. P. 159.

48 Головко О. Б. Слов'яни Північного Причорномор'я... С. 33.

49 Литаврин Г. Г. Два етюда... С. 357-359; Maiorov A. The Alliance... Р. 300; Головко О. Б. Давня Русь в системі Вуzantine Commonwealth // Східний світ. К., 2003. № 1. С. 57.

${ }^{50}$ Ипатьевская летопись. С. 741.

${ }^{51}$ Новгородская первая летопись старшего и младшего изводов. М.-Л., 1950. С. 64.

${ }^{52}$ Успенский Ф. И. Образованіе... С. 100.

${ }^{53}$ Павлов П. Руски «бродници», политически бегълци и военачалници през XII-XIV в. // Павлов П. Бунтари и авантюристи в средновековна България. Велико Търново, 2000. URL: http://liternet.bg/ publish13/p_pavlov/buntari/ruski.htm (дата звернення: 2.08.2016).

${ }^{54}$ Malingoudis Ph. Die Nachrichten des Nicetas Choniates... S. 136.

${ }_{55}$ Литаврин Г. Г. Два етюда... С. 356, 359.

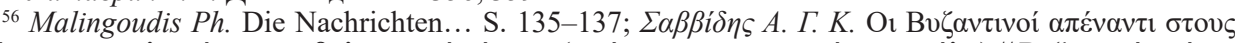

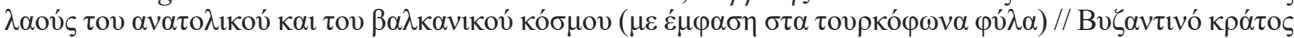

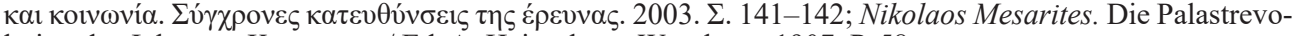
lution des Johannes Komnenos / Ed. A. Heisenberg. Würzburg, 1907. P. 58.

${ }^{57}$ Павлов П. Руски «бродници»...

${ }^{58}$ Nicetae Choniatae Historia. P. 523.43-45.

${ }^{59}$ Ibid. P. 532.15-20.

${ }^{60}$ Ibid. P. 129.29-30.

${ }^{61}$ Ibid. P. 347.39-40, 348.63-64.

62 Ibid. P. 312.2-4

${ }^{63}$ Ibid. P. 333.50-57.

${ }^{64}$ Ibid. P. 92.47-49.

${ }^{65}$ Ibid. P. 129.29-30.

${ }^{66}$ Ibid. P. 522.28. 
${ }^{67}$ Ibid. P. 402.50 .

${ }^{68}$ Успенский Ф. И. Византійскій писатель Никита Акоминатъ изъ Хонъ. СПб., 1874. С. $172-174$.

${ }^{69}$ Ioannis Cinnami Epitome rerum ab Ioanne et Alexio Comnenis gestarum // Corpus Scriptorum Historiae Byzantinae / Rec. A. Maineke. Bonnae, 1836. Vol. 23. P. 94.11-12, 115.14-16, 232.3-5, 234.22-23, 242.15-17, 246.21-22, 250.1, 262.17-18.

${ }^{70}$ Тихомиров М. Н. Древняя Русь. С. 33-34; Войтович Л. В. Границы... С. 21.

${ }^{71}$ Слово о полку Игореве / Под ред. В. П. Адриановой-Перетц. М.-Л., 1950. С. 22.

${ }^{72}$ Бибиков М. В. Byzantinorossica... С. 373.

${ }^{73}$ Тихомиров М. Н. Древняя Русь. С. 31.

${ }^{74}$ Там же. С. 34; Войтович Л. Знову про дискусію з приводу автентичності «Слова о полку Ігоревім» та стосовно його авторів // Записки НТШ. 2008. Т. 256. С. 42.

${ }^{75}$ Nicetae Choniatae Historia. P. 446. 63-75.

${ }^{76}$ Коментар до оригінального тексту «Слова о полку Ігоревім» // Слово о плъку ИгоревЂ та його поетичні переклади і переспіви. URL: http://litopys.org.ua/slovo67/sl28.htm (дата звернення: 19.08.2016).

77 Соколова Л. В. Троян в «Слове о полку Игореве» (Обзор существующих точек зрения) // Труды Отдела древнерусской литературы. Л., 1990. Т. 44. С. 325-362.

${ }^{78}$ Войтович Л. Знову про дискусію... С. 47.

${ }^{79}$ Рожко М. Ф. Карпатські шляхи та їх оборона // Український історичний журнал. К., 1990. № 10. С. 86-89; Миська P. Середньовічні шляхи в Українських Карпатах (стан та перспективи дослідження) // Археологічні дослідження Львівського університету. Львів, 2013. Вип. 17. С. 46-53.

${ }^{80}$ Павлов П. Къде в «земята на русите» е бил Иван Асен II? / Павлов П. Българското средновековие - познато и непознато: Страници от политическата и културната история на България, VII-XV век. Велико Тьрново, 2008. С. 126.

81 Летопись великого логофета Георгия Акрополита / Пер. под ред. бакалавра И. Троицкого // Византийские историки, переведенные с греческого, при Санкт-Петербургской духовной академии.

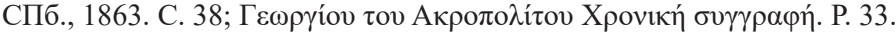

82 Павлов П. България и нейните съюзници от Северното Причерноморие (XII-XIV в.) // Българите в Северното Причерноморие. Изследования и материали. 2000. Т. 9. С. 57.

${ }^{83}$ Пашуто В. Т. Внешняя политика... С. 266.

${ }^{84}$ История Болгарии в двух томах / Под ред. П. Н. Третьякова, С. А. Никитина, Л. Б. Валева. М., 1954. Т. 1. С. 140; Цанкова-Петкова Г. България при Асеневци. С. 88, 109.

${ }^{85}$ Божилов И. Фамилията на Асеневци... С. 77; Макушевъ В. Болгарія въ конць ХІІ и въ первой половинъ ХIII въка // Варшавскія университетскія извђстія. Варшава, 1872. С. 53.

${ }^{86}$ Войтович Л. В. Галицько-болгарські відносини... С. 206, 208.

87 Там само.

${ }^{88}$ Пашуто В. Т. Внешняя политика... С. 266.

${ }^{89}$ Граля И. Царьград и Rhosia Mikra: о спорных вопросах византийско-русских отношений в XIII-XIV веках // Colloquia Russica. Материалы V Международной научной конференции, Спишская капитула, 16-18 октября 2014 г. Краков, Братислава, 2015. Т. 5. Русь и Центральная Европа в XI-XIV веках. С. 345 .

${ }^{90}$ Пашуто В. Т. Очерки по истории Галицко-Волынской Руси. М., 1950. С. 169; Вегерчук C. M. Етносоціальне походження вигнанців і бродників у Галицькому Пониззі // Наукові праці Чорноморського державного університету імені Петра Могили. Серія: Історія. Миколаїв, 2006. Т. 48. Вип. 35. С. 9.

${ }^{91}$ Головко О. Б. Слов'яни Північного Причорномор'я... С. 31; Цанкова-Петкова Г. България при Асеневци. С. 109; Войтович Л. В. Галицько-болгарські відносини... С. 209.

${ }_{92}$ Павлов П. Руски «бродници»... ; Павлов П. България и нейните съюзници... С. 57.

${ }^{93}$ Ioannis Stauracii Oratio landatoria de Sancti Myroblytae Demetrii Miraculis // Гръцки извори за българската история. София, 1980. Т. 10. Р. 129.

${ }_{94}^{94}$ Nicetae Choniatae Historia. P. 129.29-30.

${ }^{95}$ Nicephori Gregorae Historiae Byzantinae // Corpus scriptorium Historiae Byzantinae. Bonnae, 1855. Vol. 3. P. 199. 13-15, 511.17-18.

${ }^{96}$ Брунъ Ф. Догадки касательно участія русскихъ въ дълахъ Болгаріи въ XIII и XIV стольтіяхъ // Журналъ Министерства народнаго просвђщенія. СПб, 1878. Ч. 200. С. 228.

97 Павлов П. Руски «бродници»...

${ }^{98}$ Nikolaos Mesarites. Die Palastrevolution... S. 21.11-15.

${ }^{99}$ Бибиков М. В. Древняя Русь и Византия... С. 301.

${ }^{100}$ Войтович Л. В. Галицько-болгарські відносини... С. 211.

${ }^{101}$ Пашуто В. Т. Внешняя политика... С. 266. 